\title{
Основні методологічні аспекти оцінювання взаємозв'язку оборонного та економічного потенціалу держави у рамках формування вимог до її ефективного розвитку
}

\section{Олег Семененко * А; Сергій Салкуцан ${ }^{\text {B; }}$ Ольга Романченко ${ }^{\text {; }}$ Свген Марко ${ }^{\text {; }}$; Людмила Добровольська ${ }^{\text {; }}$ Артем Ремез ${ }^{\text {B }}$ \\ А Центральний науково-дослідний інститут Збройних Сил України, пр-кт Повітрофлотський 28, м. Київ, 03049, Україна

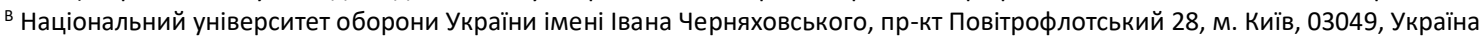 с Національний авіаційний університет, пр-кт. Любомира Гузара,1, м. Київ, 03058, Україна}

Received: December 5, 2020 | Revised: December 23, 2020 | Accepted: December 31, 2020

JEL Classification: D04, E17

DOI: $10.33445 /$ sds.2020.10.6.15

\begin{abstract}
Анотація
Національні інтереси України сьогодні потребують негайного розроблення та впровадження комплексу заходів щодо забезпечення ефективного використання наявних ресурсів з метою економічного прогресу, збільшення і зміцнення оборонного потенціалу (ОП) та воєнно-економічного потенціалу (ВЕП) держави. Дослідження проблем оцінювання та збалансованого розвитку ВЕП держави $\epsilon$ однією із головних складових проблематики подальшого розвитку України в цілому. Автори у статті зробили спробу розкрити сутність понять ОП та ВЕП держави з позицій військової науки. Наведені у статті основні теоретичні аспекти формування ОП та ВЕП держави в сучасних умовах розвитку Збройних Сил (3С) України та України в цілому дозволять сформувати основні принципи щодо розуміння цих понять та їх складових, визначити їх взаємозв'язок у сучасній військовій науці, а також обрати основні напрями проведення досліджень за такою тематикою. Аналіз ВЕП і особливо його активної частини (воєнної економіки) показує, що стан економічного забезпечення ОП України має нині значні розбіжності між його потребами та увагою, яка приділялася з боку керівництва держави його ресурсному забезпеченню. Однією із основних проблем такого стану речей $\epsilon$ досить значні невизначеності в методологічних аспектах його трактування та оцінювання. Сьогодні до основних завдань удосконалення інституційно-управлінського механізму державного керівництва щодо розвитку ОП країни належить необхідність модернізації процедур управління воєнно-економічною діяльністю, зокрема систем військового фінансування, ціноутворення на військову продукцію тощо. Але це можливо реалізувати в сучасних умовах розвитку 3 України та України в цілому тільки в разі удосконалення існуючих процедур оцінювання достатності ВЕП та ОП держави за основними складовими ї функціонування.
\end{abstract}

Ключові слова: ефективність використання наявних ресурсів, оборонний потенціал, воєнно-економічний потенціал, економічне забезпечення, системи військового фінансування, рівень обороноздатності держави, військова економіка.

\section{Постановка проблеми}

Україна має нині значний потенціал щодо наявності людських, трудових, природних, матеріальних, енергетичних, технічних, інтелектуальних, наукових, виробничих ресурсів, які у разі їх правильного використання можуть сприяти прискоренню

\footnotetext{
* Corresponding author: д. військ. н., с.н.с., начальник відділу, e-mail: aosemenenko@ukr.net, ORCID: 0000-0001-6477-3414
} 
економічного, соціального, воєнного розвитку держави шляхом створення конкурентоспроможної економіки [1-4]. Національні інтереси України потребують негайного розроблення та впровадження комплексу заходів щодо забезпечення ефективного використання наявних ресурсів 3 метою економічного прогресу, збільшення і зміцнення ОП та ВЕП держави. Дослідження проблем оцінювання та збалансованого розвитку ВЕП держави $є$ однією із головних складових проблематики подальшого розвитку України в цілому. Особливої актуальності це питання набуває в умовах бойового застосування частин та підрозділів ЗС України у виконанні завдань за призначенням, а також значних розбіжностей між потребами щодо розвитку воєнної складової держави та наявними для забезпечення цих потреб ресурсами, які реально виділяються для підтримки воєнного потенціалу (ВП) держави сьогодні. Дефіцит ресурсів суттєво залежить від сформованих у суспільстві уявлень, у тому числі теоретичних, про роль і місце військової організації (ЗС України) в системі національної безпеки країни, про об'єктивні потреби і кінцеву результативність ії діяльності в реально сформованих геостратегічних, культурноісторичних і економіко-технологічних умовах $[1,3-10]$.

\section{Аналіз останніх досліджень та публікацій}

Аналіз останніх досліджень і публікацій показав, що питанню вдосконалення існуючої системи планування розвитку 3С України 3 урахуванням реальних економічних можливостей держави із забезпечення цього розвитку приділяється сьогодні значна увага як з боку керівництва ЗС України, так i держави в цілому [1-10]. Дослідження показують, що дієвість фінансовоекономічного забезпечення будівництва 3С України можлива лише за досягнення певних економічних показників. Як основний макроекономічний показник найкращим $€$ “рівень витрат на національну оборону від валового внутрішнього продукту", визначений у розмірі не менше 3 \% від ВВП $[2,10]$. Доведення величини військових витрат до зазначеного рівня і забезпечення відповідного підвищення ресурсозабезпеченості 3С
України $\epsilon$ пріоритетним завданням військового будівництва. Нині достатньо часто висловлюються думки, що Україні необхідно декілька років (4-7) виділяти на національну оборону не менше 5-7\% з яких 4-5\% від ВВП - на розвиток ЗС України, що відповідає специфічним умовам розвитку $3 С$ України та країни в цілому. Такий рівень фінансування ЗС України та оборонної складової потрібний для якісного поступового переозброєння ЗС України з метою відповідності рівня озброєння сучасним вимогам до нього у світі. Але такі обсяги фінансування оборонної складової повинні бути тільки за умови зростання рівня ВВП не менше ніж на 4\% щорічно, що не створить додаткового навантаження на національну економіку держави $[2-6,10]$.

\section{Постановка завдання}

Тому метою статті $\epsilon$ розробка основних методологічних аспектів оцінювання взаємозв'язку оборонного та економічного потенціалу держави у рамках формування вимог до ії ефективного розвитку.

\section{Виклад основного матеріалу}

Сутність понять оборонний потенціал і воєнно-економічний потенціал достатньо часто в літературі має схожі $[2,4-7]$ і в той же час відмінні за деякими аспектами його розуміння трактування. Поняття потенціал (від латинського "potentia" - можливість, потужність) широко використовується В науковій літературі з військової тематики [4, 
5]. Розрізняють, наприклад, оборонний, військовий, ядерний, економічний, воєнноекономічний і багато інших потенціалів. Потенціал визначається як “фінанси, запаси, джерела, можливості, які $\in$ в наявності і можуть бути використані для досягнення певних цілей, рішення будь-яких завдань" [47, 10]. Однак при практичному використанні цього поняття виникають численні труднощі, пов'язані 3 відмінностями в його тлумаченнях. Ці відмінності стосуються змісту поняття конкретного потенціалу, його структури і характеристик окремих елементів, закономірностей його розвитку, шляхів і способів перетворення можливостей в реальну міць тощо. Сьогодні 3 позицій військової науки ОП можна визначити як сукупність людських, матеріальних, військових, політичних та інших об'єктивно існуючих можливостей держави, а також як здатність мобілізувати і використовувати ці можливості для забезпечення обороноздатності країни, досягнення кінцевих цілей війни [4-7]. У структурному відношенні ОП держави являє собою складну систему, елементи якої тісно пов'язані між собою, мають кількісні та якісні характеристики. Найважливішими елементами цієї системи $є$ військовий, воєнно-економічний, науковотехнічний, політичний, моральнопсихологічний потенціали [2]. У структурі ОП держави особливе місце займає власне воєнний потенціал (ВП), який у своїй основі втілюється в бойовому потенціалі ЗС України та показує рівень обороноздатності країни. Нерозривно пов'язаний 3 воєнноекономічним, науково-технічним, політичним та іншими потенціалами, ВП $\epsilon$ основним індикатором обороноздатності держави. ОП країни значною мірою залежить від політики держави, здатності її політичної системи мобілізувати і ефективно використовувати існуючі людські, матеріальні, фінансові та інші можливості країни в інтересах зміцнення ії обороноздатності [5-7]. В ОП держави значну роль відіграє його найважливіший елемент ВЕП. Економіка $\epsilon$ матеріально-технічною базою оборонних потреб. За інших рівних умов очевидно, що чим вищі економічні можливості держави, тим вище і їі ОП. Тому основними процедурами зміцнення ОП країни такі: виявлення ії економічних можливостей із забезпечення воєнного будівництва та розвитку ЗС України; вивчення масштабів, рівня розвитку і структури матеріального виробництва та існуючих об'єктивних передумов до розширення воєнно-економічної діяльності. Конкретні форми взаємовідносин між воєнним будівництвом, 3С, економікою історично змінюються залежно від загального рівня розвитку продуктивних сил, стану військової справи та інших факторів. У війнах XX ст. (перш за все світових) з'явилося якісно нове співвідношення між економікою і перебігом військових дій $[4,6]$. Якщо в минулому матеріальні потреби війни задовольнялися, головним чином, за рахунок раніше накопиченого озброєння, військової техніки та інших матеріальних запасів, то під час Першої та Другої світових воєн - переважно за рахунок поточного виробництва. Причому для цього необхідно було проведення широкої мобілізації економіки. Поява ракетно-ядерної та інших видів сучасної зброї з їх колосальною руйнівною силою, здатністю не тільки завдавати величезних втрат військам на полі бою, а й руйнувати або виводити з ладу великі економічні об'єкти і комплекси в глибокому тилу, призвела до нових якісних змін у взаєминах між воєнним будівництвом і національною економікою держави [4, 5-10]. Залежність ОП, перебігу і результату військових дій від співвідношення економічних можливостей супротивників значно ускладнилася, тому змінилися i вимоги до економіки. У роки “холодної війни", крім значного збільшення розмірів і зміни структури матеріальних потреб збройних сил, з'явилася необхідність у створенні великого і перманентно функціонуючого військового сектора економіки, завчасному створенні значних запасів озброєння та військової техніки (ОВТ), стратегічних матеріально-технічних запасів тощо. За останнє десятиліття у провідних країнах світу у зв'язку 3 кардинальними 
змінами міжнародної воєнно-політичної, економічної і військово-технічної ситуації військові реформи здійснюються з різним ступенем глибини і різними темпами. Ці реформи стосуються всіх сторін військової діяльності, в тому числі воєнно-економічної $[4,6,10]$. У багатьох країнах відбувається інтенсивне реформування військової економіки, причому найважливішим їі результатом стало посилення взаємозв'язку між військовим і цивільним секторами економіки. Розробляються нові концептуальні підходи до воєнно-економічної діяльності. Наприклад, у США стали актуальними концепція переходу від спеціалізованої воєнно-економічної бази до економічної бази для потреб оборони i концепція розвитку військово-цивільної інтеграції. Воєнно-громадянська інтеграція означає міцний взаємозв'язок військових та цивільних секторів економіки, забезпечення взаємовигідного обміну технологічними розробками і організаційно-управлінським досвідом, розроблення технологій і виробів подвійного застосування. Досвід підготовки та ведення минулих війн та масштабних конфліктів показує, що в разі необхідності розміри оборонних запасів істотно збільшуються.

Однак вони не можуть бути збільшені безмежно. У будь-якій державі в кожний конкретний період об'єктивно існує можлива верхня межа використання обмежених економічних ресурсів в оборонних цілях, що визначається її ВЕП [3-9]. Нині ВЕП трактується як максимум матеріальних засобів, що виділяються державою на військове споживання, або як частина економічного потенціалу, яка використовується безпосередньо для задоволення потреб збройних сил, або як здатність економіки забезпечити безпосередні потреби збройних сил як у мирний, так і у воєнний час тощо. Деякі автори взагалі відмовляються від поняття воєнноекономічний потенціал і для характеристики воєнно-економічних можливостей країни застосовують тільки понятя економічний потенціал, виходячи 3 того, що для економічного забезпечення підготовки i ведення війни повинні використовуватися всі економічні можливості країни [7].

Зустрічаються істотні розбіжності не тільки у визначенні сутності ВЕП, а й щодо складу його основних елементів $[7,12]$. Розбіжності $\epsilon$ i щодо взаємозв'язку ВЕП 3 іншими потенціалами. Існуючі відмінності У визначенні ВЕП, його структури та взаємозв'язку 3 іншими потенціалами підкреслюють виняткову складність ВЕП як явища реальної дійсності $[6,9,10]$. Визначення та структуризація ВЕП, виділення його головних елементів, що визначають його розміри, характер, тенденції розвитку, можливі способи нарощування $\mathrm{i}$ використання, $€$ однією 3 найважливіших теоретичних і методологічних проблем дослідження ВЕП, оцінювання його ролі i місця в ОП держави [7, 12] (мал. 1).

Воєнно-економічний потенціал держави можна визначити як максимальний рівень економічного забезпечення конкретних потреб збройних сил, підготовки і ведення війни, який може бути досягнутий у певні терміни за найбільш напруженого використання продуктивних сил країни у військових цілях і допустимого рівня задоволення цивільних потреб [3, 4-9]. Воєнно-економічний потенціал держави визначається ії загальним економічним потенціалом. Жодна країна не може навіть у ході великої війни використовувати весь свій економічний потенціал для задоволення військових потреб. Перш ніж направити ті чи інші ресурси на військові цілі, держава повинна задовольнити хоча 6 у мінімальному розмірі свої цивільні потреби, які змінюються з розвитком продуктивних сил і мають свої національні особливості, спричинені конкретними умовами розвитку країни. 3 огляду на це, визначається максимальна частина економічного потенціалу, яка може бути використана у військових цілях. У мирний час у військових цілях використовується значно менша частина ВЕП, ніж в умовах війни. 


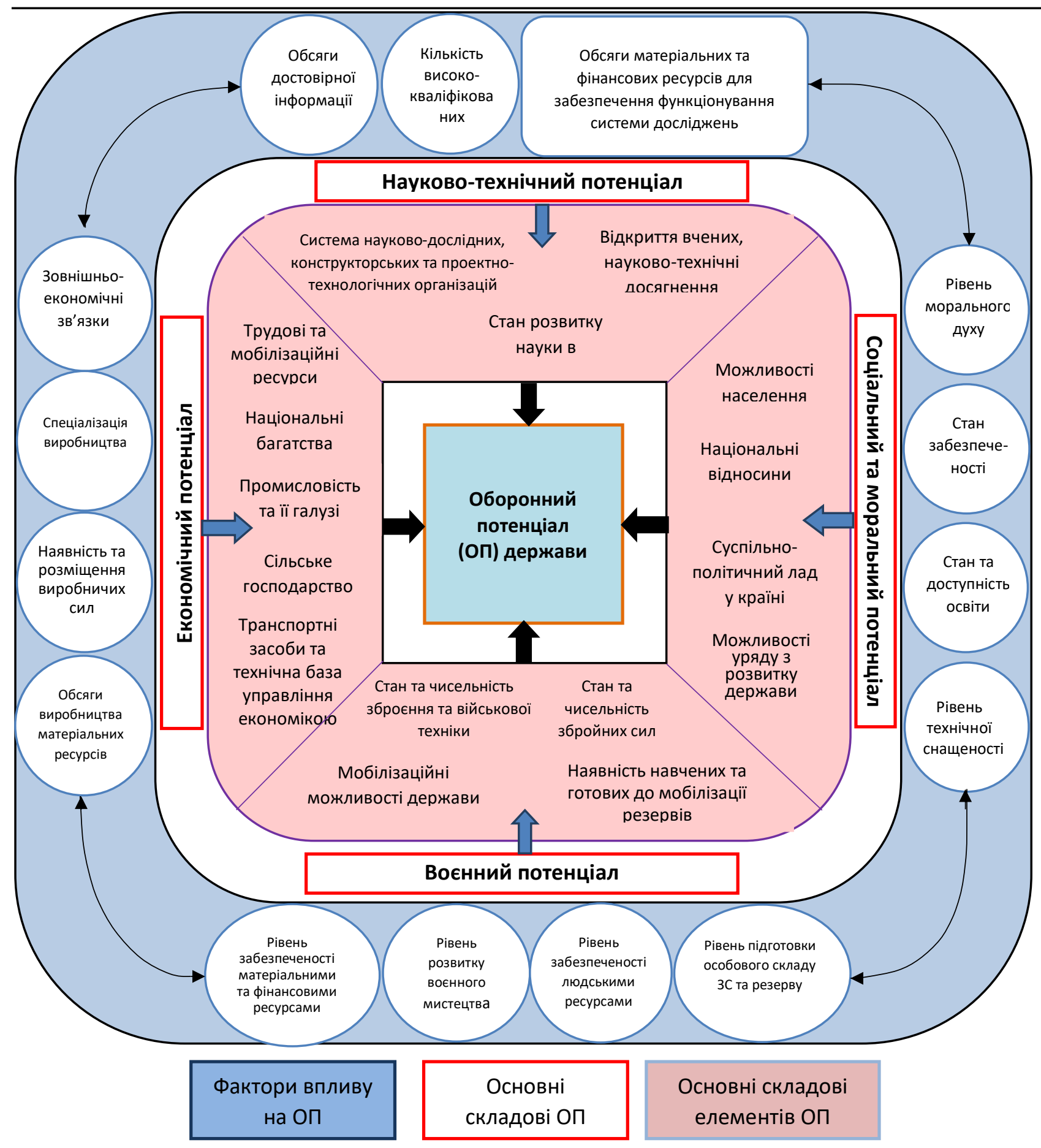

Малюнок 1 - Державних програм розвитку (ДПР) ЗС України за період 2000-2020 років (за показниками: середній рівень фінансування ДПР відносно показників потреб за період дії ДПР, середні обсяги неефективно використаних коштів, середні обсяги коригування Планів утримання та розвитку зС України за період дії ДПР, середні розбіжності між рівнями фінансування та виконання ДПР)

Найбільшою мірою ВЕП реалізується в умовах великомасштабної війни, коли здійснюється загальна мобілізація господарства країни, його переведення на воєнний стан 3 метою максимального задоволення потреб війни.

Поняття ВЕП характеризує об'єктивно існуючі у державі максимальні можливості із задоволення воєнних потреб у разі втягування ії у війну. У кожному конкретному випадку ступінь практичного використання цих можливостей, рівень їх перетворення в реальну воєнно-економічну могутність визначаються багатьма причинами: воєнно- 
політичними, економічними та військовотехнічними. Також $є$ думка, що ВЕП держави можна вважати частиною економічного потенціалу (ЕП) [7], що відображає воєнноекономічні можливості держави, які можуть бути спрямовані на задоволення матеріальних потреб та на комплектування ЗС для ведення війни:

$$
B E \Pi=K_{8} \cdot E \Pi,
$$

де ВЕП - воєнно-економічний потенціал, \%;

$K_{\varepsilon}-$ коефіцієнт використання економічного потенціалу $\left(0<K_{B}<1\right)$;

ЕП - економічний потенціал, \%.

Тобто за такого підходу ВЕП - це сукупність економічних ресурсів держави, які можуть бути виділені та використані для нарощування економічних основ воєнної могутності держави. Стан ВЕП залежить від ряду факторів: розвитку виробничих сил; характеру виробничих відносин; політичного та економічного устрою держави; від того, до якої коаліції належить держава, тощо. Основні напрями використання досягнень науки та техніки у воєнній економіці націлені на забезпечення першочергового розвитку тих галузей науки і техніки, які дають можливість у найкоротші строки та найбільш ефективно задовольняти як громадянські, так і оборонні потреби держави. До них належать: автоматизація виробництва; розвиток біотехнологій; впровадження гнучких технологій, що дозволяють швидко перебудовувати виробництво; використання атомної та термоядерної енергії; отримання матеріалів із заданими властивостями тощо. Такі досягнення повинні сприяти підвищенню рівня обороноздатності держави за рахунок оснащення Збройних Сил новітнім озброєнням та воєнною технікою, використання передових технологій та матеріалів. Сьогодні у засобах масової інформації часто говорять про негативний вплив оборонних витрат на економічний розвиток країни та планують за рахунок їх скорочення вирішити накопичені економічні та соціальні проблеми. Однак за оцінками експертів оборонно-промисловий комплекс $\epsilon$ одним з основних резервів, що дає можливість у взаємодії з іншими секторами економіки розраховувати на забезпечення країною статусу індустріально незалежної держави. Він $€$ невід'ємною складовою частиною воєнного потенціалу країни та промисловою основою національної безпеки держави. Оборонні витрати реалізуються і впливають на економічний розвиток оборонно-промислового комплексу, який виробляє озброєння, військову техніку, послуги національної оборони та іншу оборону продукцію. Саме в цьому комплексі народжується високі технології, ноу-хау, що згодом можуть застосовуватись й у цивільних галузях економіки [6]. Стабільна робота підприємств і організацій ОПК не тільки створює передумови для розвитку наукової сфери і суміжних галузей промисловості, але й сприяє переходу від сировинної моделі економіки до моделі інноваційного розвитку. Одним з найбільш серйозних аргументів на користь розвитку ОПК $\epsilon$ розвиток нових технологій, таких як: супутниковий зв'язок, навігація, авіабудування, модернізація реактивних двигунів, розвиток систем зв'язку тощо. Величину та характер реального впливу воєнних витрат на економіку багато в чому визнається загальним рівнем розвитку економіки конкретної країни. Тому для виявлення характеру їх впливу необхідно провести аналіз економічного розвитку за відповідний період. Наприклад на мал. 2 (2.1, $2.2,2.3,2.4,2.5,2.6)$ наведені результати порівняльного аналізу розвитку оборонної сфери (воєнно-економічного потенціалу) деяких країн світу станом на кінець 2019 року за показниками оборонних витрат в млрд. дол. США та частки від ВВП, а також показників чисельності 3 Са показників доданої вартості промисловості за роками у млрд. дол. США.

У сучасних умовах розвитку України належне задоволення потреб 3 С одним 3 пріоритетних завдань України. 3 самого початку створення задоволення їх потреб здійснювалося далеко не в повному обсязі більша частина коштів спрямовувалася на утримання (мал. 3), а не на модернізацію, а постійне зменшення кількості державного 
оборонного замовлення (ДОЗ) та витрат на морального та фізичного старіння техніки. потреби ОПК призвели до безповоротного

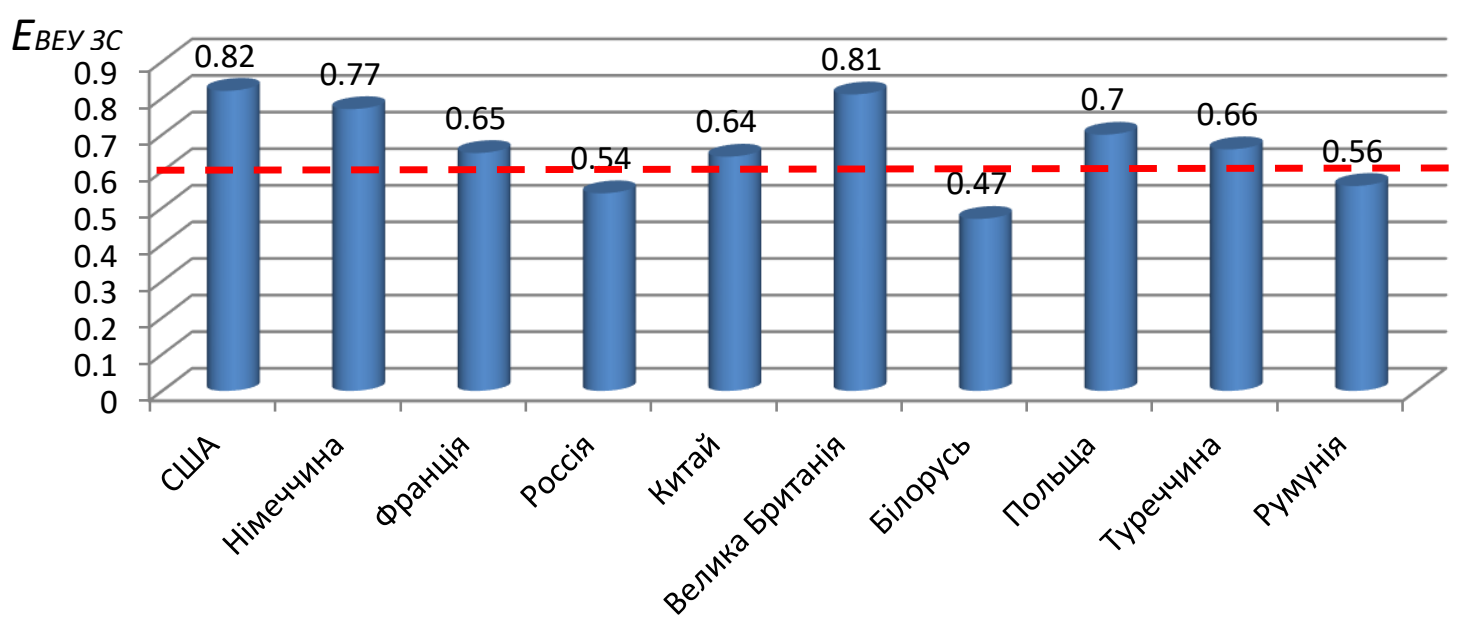

Малюнок 2 - Стан розвитку оборонної сфери (ВЕП) країн світу станом на кінець 2019 року

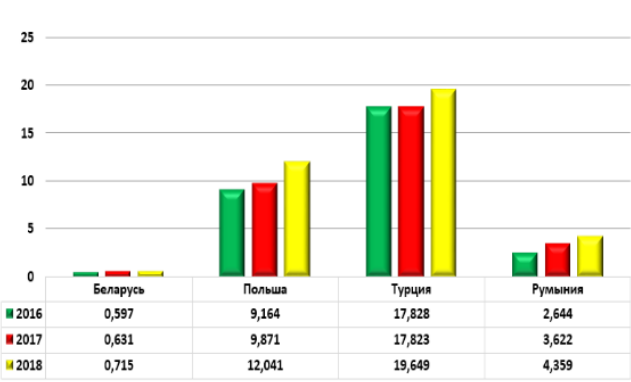

Малюнок 2.1 - Динаміка оборонних витрат суміжних з Україною країн, млрд. дол. США

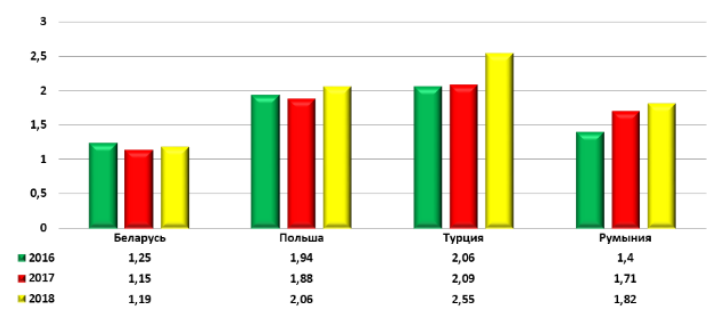

Малюнок 2.3 - Динаміка оборонних витрат суміжних з Україною країн відносно ВВП, \% 2500000

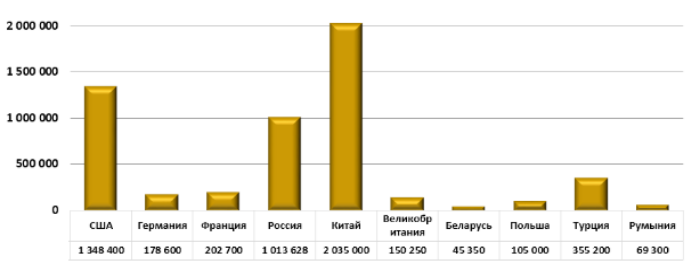

Малюнок 2.5 - Чисельність 3С деяких країн світу, чол.

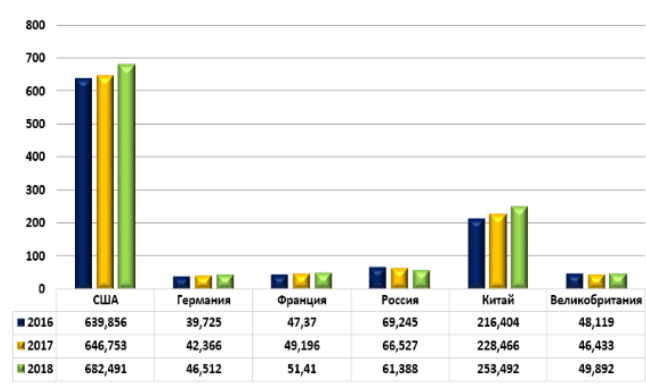

Малюнок 2.2 - Динаміка оборонних витрат провідних країн світу, млрд. дол.

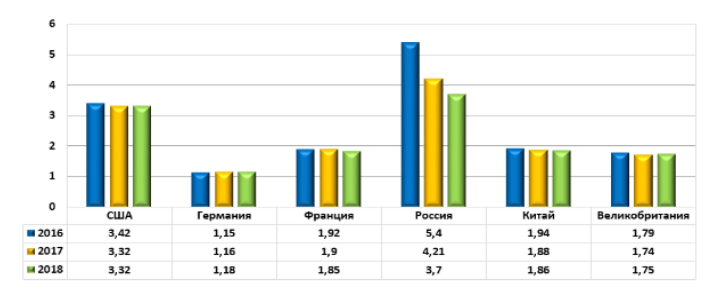

Малюнок 2.4-Динаміка оборонних витрат провідних країн світу відносно ВВП, \%

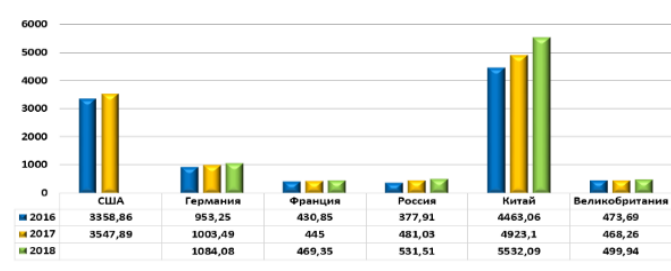

Малюнок 2.6 - Додана вартість промисловості за роками, млрд. дол. США 
Розвиток ОПК, зазвичай, визначає та забезпечує зміну науково-технічного прогресу (НТП); вирішує задачі щодо імпортозаміщення та оновлення на новій технологічній основі таких галузей економіки, як паливно-енергетична та агропромисловий

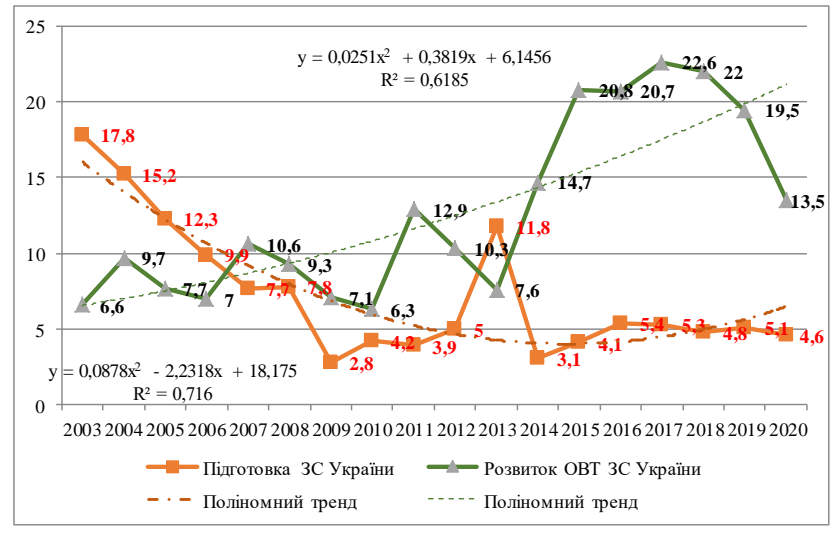

комплекси, транспорт, зв'язок, медицина; розширює експортні можливості держави. Тому, і величини ДОЗ опосередковано можуть суттєво впливати на зміну рівня економічної безпеки країни.

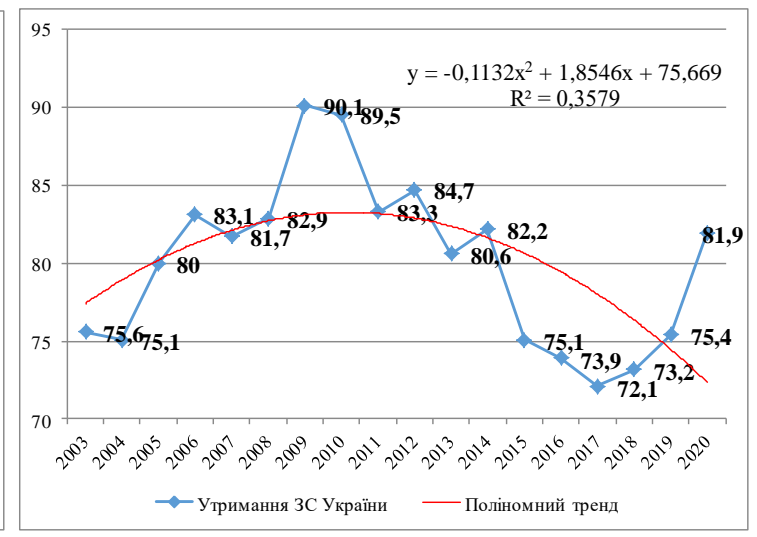

Малюнок 3 - Показники розподілу оборонного бюджету України (2003-2020рр.)

Одночасно зі зменшенням фінансування потреб 3С відбувалися негативні темпи змін основних макроекономічних показників країни: ВВП, прямих іноземних інвестицій, промислового виробництва тощо. Тобто, фактично відбувався тотальний спад не тільки виробничих можливостей, а й уповільнення темпів економічного зростання України. Економічна ситуація, що зараз склалася в країні, дає привід до більш ретельних досліджень позитивного та негативного впливів збільшення воєнних витрат на їі економічне зростання, як однієї зі складових економічної безпеки України. Аналіз останніх досліджень, публікацій та низки документів свідчить, що більшість статей 3 воєнноекономічної тематики присвячена лише кількісно-якісному аналізу статистичної бази воєнних витрат. Хоча проблеми аналізу достатності економічних можливостей держави та показників розвитку ЗС України $\epsilon$ сьогодні надзвичайно актуальними та необхідними [1-11]. Леонтьєв В. В., що був одним з найперших економістів, дослідив зміну впливу воєнних витрат на стан макроекономічних процесів держави та проаналізував вплив воєнних витрат на стан економіки 3 6-ти можливих варіантів розвитку (сценаріїв) відповідно до встановлених дій [15]. У більшості випадків був здійснений висновок, що економічний вплив істотного послідовного скорочення світових воєнних витрат надасть стимулюючий вплив на світову економіку в цілому і на економіку більшості регіонів, особливо на сектори, які виробляють основні споживчі товари. Сьогодні сутність поняття економічної мобільності держави полягає в тому, що під час переходу з мирного на воєнний стан, з метою задоволення потреб в озброєнні та військовій техніці (ОВТ), а також в інших матеріальних засобах в інтересах будівництва 3С та ведення бойових дій передбачається: організація виробництва за планом війни; перебудова роботи транспорту, зв'язку, капітального будівництва; розгортання НДДКР із розрахунком нових оборонних задач; проведення заходів щодо підвищення стійкості функціонування воєнної економіки та народного господарства в цілому.

Перетворення ВЕП у реальну воєнноекономічну міць, так званий рівень обороноздатності держави, відбувається через воєнну економіку, яка націлена на виробництво великого переліку видів продукції військового призначення, в першу чергу, ОВТ. Воєнну економіку умовно можна 
вважати активною частиною ВЕП, бо виробничий апарат діючих військових підприємств забезпечує задоволення конкретних військових потреб. Функціонування цих підприємств вже означає реалізацію ВЕП. Невикористані в кожний конкретний відрізок часу у військових цілях потенційні військово-економічні можливості країни можна вважати пасивною частиною ВЕП. Практичне використання пасивної частини ВЕП здійснюється шляхом ї̈ переходу на військові рейки, розширення військової економіки.

Таким чином, реалізація ВЕП пов'язана з розвитком військової економіки, кордони якої еластичні в рамках ВЕП країни. Співвідношення між активною і пасивною частиною ВЕП в різних країнах або в одній і тій же країні в різні періоди може бути різним. Країна з великим ВЕП може поступатися за рівнем розвитку військової економіки країні $з$ меншим ВЕП (мал. 4).

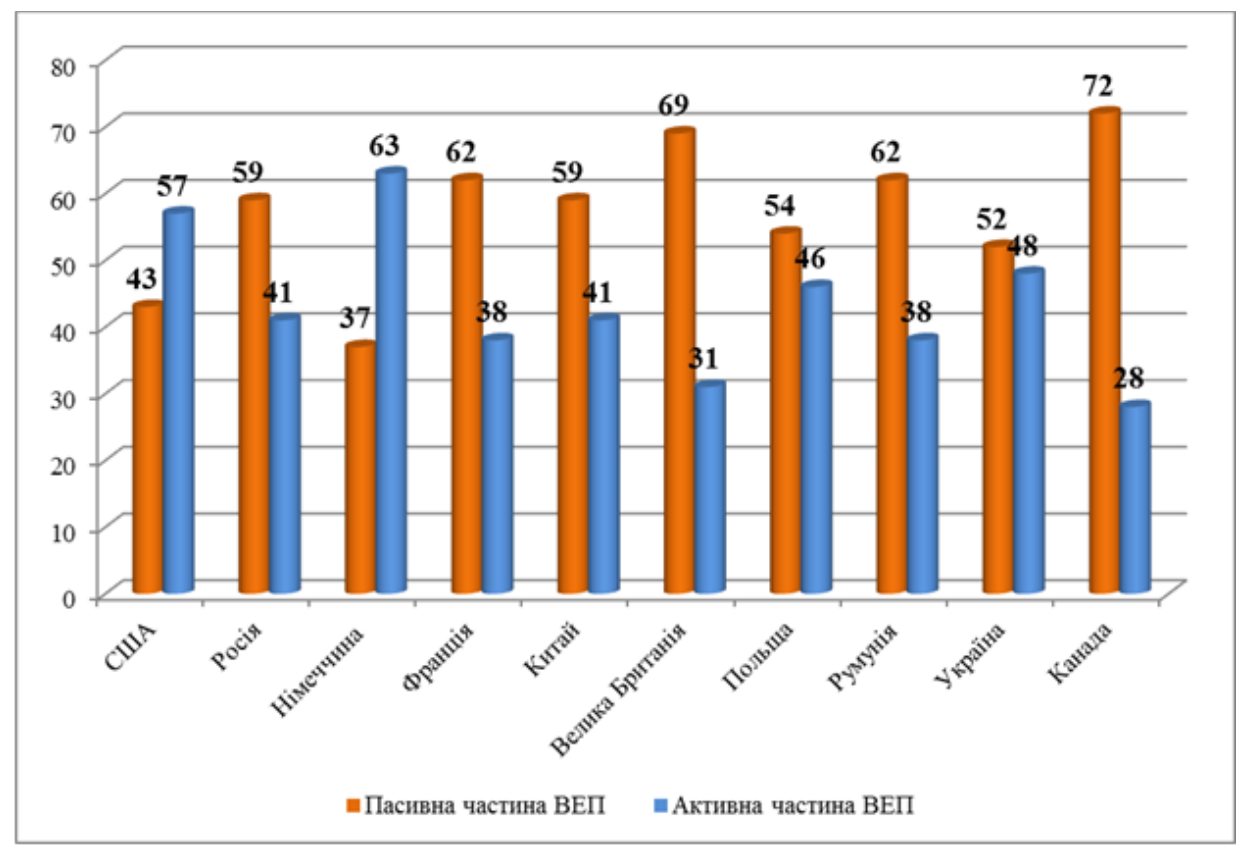

Малюнок 4 - Експертні оцінки щодо розподілу воєнно-економічного потенціалу на активну і пасивну частини для деяких країн світу станом на кінець 2019 року

Розподіл ВЕП на активну і пасивну частини має важливе методичне значення з точки зору можливостей мобілізаційного розгортання національної економіки у разі загострення воєнно-політичної обстановки навколо країни. Країни з відносно більшою активною частиною ВЕП мають можливість швидше у значно більших розмірах здійснити мобілізаційне розгортання економіки в оборонних цілях, ніж країни, в яких ця частина ВЕП відносно менша. Однак можливі максимальні масштаби розвитку воєнної економіки, виробництва продукції оборонного призначення за інших рівних умов визначаються розмірами ВЕП країни. Масштаби ОП держави визначаються кількісними і якісними характеристиками ії збройних сил і продуктивних сил: людських ресурсів, виробничих потужностей, їх структури і територіального розміщення, інфраструктури, забезпеченості природними ресурсами (особливо основними видами сировини та палива), сільського господарства, транспорту і зв'язку, рівня розвитку науки і техніки, розмірів національного багатства, запасів золота та іноземної валюти, стратегічних резервів різних матеріальних засобів та ін. Ці елементи нерозривно пов'язані між собою, їх роль і значення в ОП історично змінюються. Для того щоб досить обґрунтовано оцінити ОП, необхідно комплексно досліджувати його головні елементи, в тому числі виявити максимальні можливості їх використання у 
військових цілях. Оцінювання якісних i кількісних аспектів ОП, ВЕП та їх найважливіших елементів належить до переліку недостатньо відпрацьованих в теоретичному і практичному плані проблем. Вирішення цієї надзвичайно складної проблеми вимагає застосування цілого ряду критеріїв, вартісних і натуральних показників, статистичних та економіко-математичних методів, експертних оцінок тощо. Під час

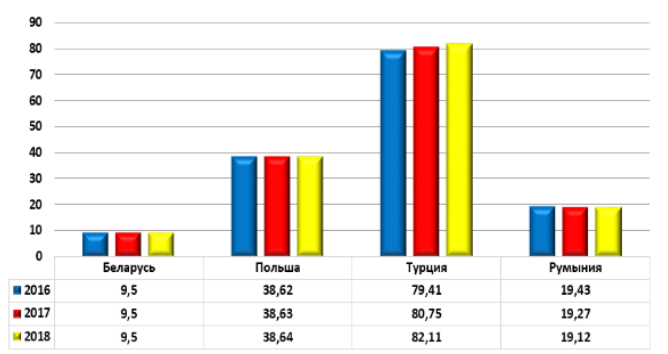

дослідження кожного елемента ОП та ВЕП виникає необхідність використовувати особливі критерії та показники. Наприклад, найважливішим показником оцінки стану людських ресурсів, які завжди були і залишаються найголовнішим елементом ОП $\mathrm{i}$ ВЕП, є чисельність населення. На відміну від інших країн світу, чисельність населення України останнім часом скорочується (мал. 5).

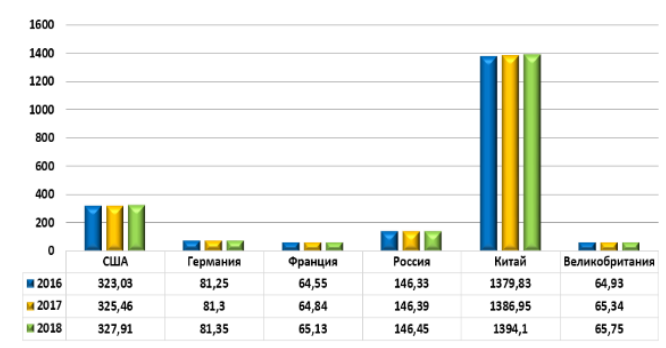

Малюнок 5 - Динаміка чисельності населення суміжних з Україною та провідних країн світу

Ця тенденція, очевидно, збережеться і в найближчі роки. 3 точки зору воєнної безпеки велике значення мають не тільки кількісні показники, а й якісні критерії. Найважливішими серед них $€$ : здоров'я населення, його загальноосвітній рівень та морально-психологічний стан, вікова структура в цілому і працездатного контингенту зокрема, кваліфікаційнопрофесійний склад трудових ресурсів. У сучасних умовах ОП та ВЕП багато в чому залежать від промислового потенціалу країни. Для його кількісної характеристики використовуються різні вартісні і натуральні показники, які дозволяють оцінити максимальні виробничі потужності країни 3 випуску тих чи інших видів продукції, у тому числі і військового призначення. Якісний стан промисловості характеризують такі показники, як продуктивність праці, ступінь механізації та автоматизації виробничого процесу, наукоємність, фондозабезпеченість і енергозабезпеченість праці. Сьогодні Україна втратила багато виробничих об'єктів та частину території, тривають небезпечні процеси фізичного і морального зносу основних виробничих фондів, втрати конкурентоспроможності цілих секторів економіки. Спостерігається явна тенденція до деіндустріалізації країни, відбуваються несприятливі зміни у структурі промислового виробництва: різке зменшення в ньому частки обробної промисловості і значне збільшення частки сировинних секторів [1], [12]. Несприятливі зміни у промисловості неминуче призводять до ослаблення матеріальної бази обороноздатності країни, а в довгостроковій перспективі можуть створити критичну ситуацію з точки зору економічного забезпечення воєнного будівництва.

У структурі ОП повинна зростати роль науки і техніки. Науково-технічний потенціал став одним із ключових елементів ОП держави (мал. 1). Дослідження науковотехнічного потенціалу ускладнюється через специфічні особливості його розвитку. Річ у тім, що відсутній прийнятний єдиний критерій оцінювання загального рівня науково-технічного розвитку. У загальному вигляді науково-технічний потенціал, як елемент ОП, можна оцінити можливістю країни зі створення якісно нового озброєння з використанням новітніх наукових досягнень і передових технологій. Науково-технічний потенціал визначається не тільки загальним рівнем розвитку науки і техніки, а й його структурою, а також здатністю технічної бази 
до освоєння новітніх науково-технічних досягнень. Створення сучасних складних систем зброї вимагає широкого розгортання НДДКР в цілому переліку галузей знань і високого технологічного рівня виробничої бази. Важливими кількісними показниками оцінки науково-технічного потенціалу слугують масштаби і структура проведених НДДКР, чисельність і рівень підготовки наукових i інженерно-технічних кадрів, матеріально-технічна база наукових досліджень. На жаль, Україна нині на розвиток науки виділяє достатньо обмежені фінансові ресурси, фінансування військової науки взагалі до 2015 року перебувало в критичному стані, тільки реальні військові загрози з боку Росії розкрили катастрофічний стан науково-технічної складової оборонної сфери держави [1], [10], [12].

Елементи ОП та ВЕП функціонують i розвиваються не ізольовано, а в тісному взаємозв'язку, причому як у рамках окремих країн, так і на світовій арені. При цьому глобалізація світової економіки супроводжується посиленням взаємодії ОП окремих країн. Входження України у світову економіку, розширення ії економічних зв'язків з іншими країнами можуть мати для ОП країни як позитивні, так і негативні наслідки. Наприклад, для економічного забезпечення обороноздатності В довгостроковому плані серйозною загрозою стала наша залежність від зарубіжних поставок, особливо з боку Росії. Україна перетворилася на країну, яка безпосередньо залежить від імпорту чисельних базових видів техніки, продовольства, технологій тощо. До основних загроз національній безпеці України також належать величезна зовнішня заборгованість України. Державний борг України зростає щороку та вже наближається до розміру її ВВП (табл. 1) [15].

Таблиця 1 - Державний борг у деяких країнах світу за 2012-2019 роки (\% від ВВП)

\begin{tabular}{|l|c|c|c|c|c|c|c|c|}
\hline \multirow{2}{*}{ Країна } & \multicolumn{7}{|c|}{ Значення показників по роках } \\
\cline { 2 - 9 } & $\mathbf{2 0 1 2}$ & $\mathbf{2 0 1 3}$ & $\mathbf{2 0 1 4}$ & $\mathbf{2 0 1 5}$ & $\mathbf{2 0 1 6}$ & $\mathbf{2 0 1 7}$ & $\mathbf{2 0 1 8}$ & $\mathbf{2 0 1 9}$ \\
\hline Росія & 27,62 & 30,14 & 27,59 & 35,28 & 42,75 & 33,72 & 28,09 & 26,2 \\
\hline Білорусь & 52,57 & 54,33 & 52,37 & 70,85 & 82,39 & 75,16 & 67,67 & 78,9 \\
\hline Туреччина & 39,06 & 41,44 & 43,85 & 47,05 & 47,91 & 54,27 & 58,97 & 53,2 \\
\hline Румунія & 71,82 & 66,35 & 56,73 & 55,53 & 52,36 & 55,3 & 47,98 & 48,87 \\
\hline Україна & 77,39 & 81,37 & 96,11 & 130,62 & 124,44 & 105,73 & 89,63 & 92,5 \\
\hline Зона євро & 22,22 & 24,15 & 24,37 & 26,07 & 27,72 & 28,97 & 27,78 & 29,42 \\
\hline
\end{tabular}

Використання державою зовнішніх та внутрішніх позик зумовлено нестачею власних фінансових ресурсів, необхідних для виконання боргових зобов'язань, покриття дефіциту державного бюджету, фінансування проектів, підтримки національної валюти тощо. Зміна обсягів заборгованості, зростання виплат за боргом також здійснює певний вплив на формування показника ВВП. У табл. 1 представлено динаміку показників державного боргу деяких країн порівняно 3 Україною (2012-2018 рр.). Аналіз наведених показників засвідчує, що провідні країни мають достатньо значні показники державного боргу, що, нібито, повинно негативно відбиватися на стані їх економіки, бо наявність показників боргу передбачає щорічні платежі для його повернення. Але в цих показниках значну частку боргу займає внутрішній борг, тобто держава взяла в борг у власного населення, а не у зовнішніх інвесторів. Дещо інша ситуація в країнах, суміжних з Україною. Зростання фінансовоекономічної залежності від інших країн створює передумови до того, що Україна перетворюється у постачальника сировини для розвинених держав, що зумовлює відтік фінансових та трудових ресурсів з країни в достатньо великих обсягах. Сьогодні під час оцінювання ОП та ВЕП держави не можна обмежуватися тільки дослідженням поточного стану основних елементів. Це 
особливо справедливо для сучасної України, економіка якої періодично зазнавала значних коливань, що негативно відбивалося на усіх складових національних інтересів України та на їі населенні. Визначені та висвітлені статистичні показники щодо розвитку національної економіки України не завжди адекватно відображають потенційні можливості країни. Україна нині все ще має достатні можливості для швидкого розвитку економіки і зміцнення ОП та ВЕП, але треба чітко і виважено здійснювати оцінювання цих можливостей та обґрунтувати їх ефективне використання. Це повинно стати одним із головних завдань подальшого розвитку воєнно-економічної науки. Для дослідження економічних основ ОП надзвичайно важливе значення має не тільки вивчення головних елементів продуктивних сил, а й виявлення сукупних максимальних воєнно-економічних можливостей держави 3 урахуванням особливостей та закономірностей їх взаємодії. Величини ОП і ВЕП змінюються під впливом розвитку різних факторів, які пов'язані із розвитком продуктивних сил, науково-технічного прогресу, змін у їх основних елементах. Нині важко визначити показник, який дозволив би дати точну кількісну характеристику ОП та воєнноекономічного потенціал ВЕП, бо вони мають достатньо широке трактування, але оцінювання цих величин повинно бути. Наприклад, як один із критеріїв оцінювання ОП або воєнно-ВЕП може бути використаний показник здатності збройних сил виконувати поставлені перед ними завдання У визначений часовий інтервал їх будівництва та розвитку (так звана боєготовність 3 ).

Бойова готовність $3 \mathrm{C}$ - це їх здатність в будь-яких умовах обстановки почати військові дії в установлені строки та успішно виконати поставлені завдання. Рівень бойової готовності військ являє собою системну єдність технічної оснащеності, військової майстерності і стану морального духу. Здатність військ виконувати поставлені перед ними завдання значною мірою залежить від того, як організована їх діяльність, створення, модернізація, ремонт і утримання ОВТ, фінансування військових потреб. Треба розуміти сьогодні, що будь-яка діяльність повинна мати: мету; засоби; процес; результат. Результат узагальнено характеризується двома показниками ефектом та витратами фінансових ресурсів. Складний і неоднозначний процес діяльності військової організації можна представити як сукупність окремих заходів. Під заходом розуміють будь-яку цілеспрямовану діяльність у рамках воєнно-економічних відносин у процесі виробництва, розподілу, обміну (обігу) і споживання кінцевого військового продукту, причому цей процес можна вивчати з різних точок зору. Оскільки воєнно-економічний аналіз має на меті підвищення ефективності використання ресурсів, то предметом аналізу $є$ специфічні економічні відносини, що виникають 3 приводу пошуку найбільш ефективних шляхів використання матеріальних, трудових і фінансових ресурсів для виконання завдань, що стоять перед воєнною системою держави [13], [14]. Тому необхідно використовувати методи обґрунтування планів заходів щодо забезпечення бойової готовності військ (з урахуванням витрат на їх проведення) та результату, що досягається, так званого ефекту діяльності.

3 усіх макроекономічних показників найбільш придатним для кількісного оцінювання і зіставлення ВЕП окремих країн $€$ відомості про валовий внутрішній продукт, національний дохід, національне багатство тощо. Зміни макроекономічних показників провідних країн світу впливають на їх воєнноекономічні можливості, а отже, на їх ОП та ВЕП. Результати оцінювання ВЕП дозволять мати тільки наближене уявлення про воєнноекономічні можливості країни. На основі показників про ВВП не можна визначити граничні можливості держави із забезпечення конкретних економічних потреб ЗС. Для загальної оцінки ВЕП потрібно виявити сукупні максимальні воєнноекономічні можливості національної економіки країни в єдності та взаємозв'язку функціонування основних елементів економіки. Під час оцінювання ВЕП необхідно 
мати не тільки достатню аналітичну інформацію про основні його елементи, а й відомості про характер майбутньої війни, попит на військову техніку та інші види кінцевої військової продукції. Це потрібно для визначення пропорцій у розподілі матеріальних і трудових ресурсів між секторами воєнного виробництва.

Упродовж останніх років у США і в інших провідних західних країнах відбуваються значні зміни у воєнно-економічній сфері. Ці країни здійснюють комплекс заходів з метою пристосування воєнної економіки до нових вимог і умов. Особлива увага приділяється розробленню принципово нових систем зброї, створення з використанням можливостей сучасної інформаційної i комунікаційної техніки потенціалу ведення війни нового типу, зокрема потенціалу неядерного удару, направленого на роззброєння, що було продемонстровано під час військових операцій в Югославії, Іраку, Лівії. У цих швидко мінливих умовах не можна точно оцінити ВЕП без оцінювання поточних і потенційних науково-технічних, виробничих та інших можливостей країни 3 виробництва систем озброєння і створення потенціалу, необхідного для ведення сучасних війн. 3 усіх відомих методів оцінювання ВЕП найбільш прийнятним $€$ метод розрахунку міжгалузевої балансової моделі мобілізаційного розгортання національної економіки в умовах війни [15]. Ця модель дозволяє визначити взаємозв'язок між різними секторами економіки, дати кількісну оцінку можливої максимізації випуску воєнної продукції, скорочення виробництва цивільної продукції до допустимих мінімальних розмірів. Під час формування такої балансової моделі виходять $з$ передумови, що в ході мобілізаційного розгортання економіки здійснюється гранично інтенсивне комплексне використання існуючих в країні продуктивних сил.

\section{Висновки}

Аналіз ВЕП і особливо його активної частини (воєнної економіки) показує, що стан економічного забезпечення ОП України має нині значні розбіжності між його потребами та увагою, яка приділялася з боку керівництва держави для його ресурсного забезпечення. Однією із основних проблем такого стану речей $\epsilon$ досить значні невизначеності в методологічних аспектах його трактування та оцінювання. Сьогодні до основних завдань удосконалення інституційно-управлінського механізму державного керівництва щодо розвитку ОП країни можна віднести необхідність модернізації процедур управління воєнно-економічною діяльністю, зокрема систем військового фінансування, контрактації, ціноутворення на військову продукцію тощо. Але це можливо реалізувати в сучасних умовах розвитку ЗС України та України в цілому тільки у разі удосконалення існуючих процедур оцінювання достатності ВЕП та ОП держави за основними складовими їх функціонування. Поява якісно нової зброї, форм і способів збройної боротьби пред'являє все нові вимоги до ВЕП країни, до системи економічного забезпечення військового будівництва. Без урахування цих обставин зараз наразі неможливе вироблення воєнно-економічної політики i стратегії розвитку держави в цілому, а також ефективного реформування ОПК, управління основними елементами ОП. Розроблення процедур оцінювання ОП і ВЕП України дозволить оцінювати ступінь їх достатності потребам, які формуються в системі оборонного планування під час розроблення Державних програм розвитку ЗС України на середньострокову та довгострокову перспективу, що, в свою чергу, посприяє підвищенню ефективності їх виконання та формування шляхом зростання обґрунтованості рішень щодо визначення заходів розвитку ЗС України та рівня їх забезпеченості фінансовими ресурсами. Подальшого дослідження також потребує питання розвитку теоретичних та методологічних основ оцінювання внеску основних складових потенціалу у загальний 
рівень ВЕП, а також у розвиток ЗС України або ОП держави в цілому з метою формування рекомендацій щодо підвищення ефективності розвитку ЗС України та держави в цілому.

\section{Список використаних джерел}

1. Проблеми і напрями розвитку Збройних Сил України в сучасних умовах. URL: http://www.niss.gov.ua/content/articles/ files/ZSU-73823.pdf.

2. Семененко О. М., Бойко Р. В., Водчиць О. Г., Добровольський Ю. Б., Бердочник Д. В., Ярошенок А. В. Основні методологічні аспекти воєнно-економічного забезпечення обороноздатності держави: теорія та практика // Системи обробки інформації: щокварт. наук.-тех. журн. Харків: ХНУПС, 2017. № 3 (51). С. 165-175.

3. Рудь І. Стратегія сталого розвитку «Україна2020»: цілі, напрями, пріоритети (Центр досліджень соціальних комунікацій). URL: http://nbuviap.gov.ua/index.php?option=com

4. Семененко О. М. Методологічні основи воєнно-економічного супроводження програм розвитку Збройних Сил України: дис. ... докт. військ. наук: 20.01.05/ Семененко Олег Михайлович. Київ: ЦНДІ ЗС України, 2018. 640 с.

5. Викулов С. Ф. Методология оценки оборонного и военно-экономического потенциалов государства / Центральный экономико-математический институт РА. URL: https://cyberleninka.ru/article/n/ metodologiya-otsenki-oboronnogo-i-voennoekonomicheskogo-potentsialov-gosudarstva/ viewer.

6. Хрусталёв Е. Ю. Оборонный потенциал России в контексте современной международной конкуренции и глобализации. URL: https://cyberleninka.ru/ article/n/oboronnyy-potentsial-rossii-vkontekste-sovremennoy-mezhdunarodnoykonkurentsii-i-globalizatsii.

7. Мунтіян В. І. Економіка та оборонні витрати: аналіз зарубіжних досліджень і український шлях розвитку. Київ: Наук.-дослід. фін. ін-т при М-ві фінансів України, 1998. 463 с.

8. Черняк О. І., Харламова О.І. Конвергенція витрат на оборонний комплекс та економічний розвиток країни // Вісник
КНУТШ. 2013. № 23. С. 36-41.

9. Семененко О. М., Бойко Р. В., Водчиць О. Г., Масловський С. С., Кремешний О. І., Корнієнко А. П. Основні методологічні аспекти воєнно-економічного обґрунтування перспективних напрямів розвитку Збройних Сил України // Зб. наук. пр. ХНУПС. Харків. 2018. № 1 (55). С. 37-45.

10. Обгрунтування рекомендацій щодо удосконалення механізму формування програм і планів реформування та розвитку Збройних Сил України під час здійснення оборонного планування: звіт про НДР «Меридіан - ОП» (заключн.) / ЦНДІ ЗС України; кер. Потапов Г. М.; викон.: Семененко О. М., Абрамов А. П. та ін. Київ. 2015. 137 с. № ДР $0101 \cup 001854$.

11. Семененко О. М., Корнийчук С. П., Бокий В. Г., Каблуков О. А. Современные особенности военно-экономического обеспечения $и$ оценки необходимого уровня обороноспособности Украины // SDirect 24 - Safety, Society, Science. 2020. № 2 (12). P. 51-76. URL: https://www.sdirect24.org/kopia-natodeep-no-13

12. "Try roky ATO. Vysnovky ta perspektyvy stanom na 14.04.2017 roku", available at: [Three years ATO. Conclusions and prospects as at 14.04.2017] URL: https:// espreso.tv/.../2017/.../try_roky_ato_yak_ pochynalosya.

13. Радвик Б. Военное планирование и анализ систем сокр. перевод с англ. В. Базарова, Л. Какунина, К.Трофимова под ред. А. М. Пархоменко Москва: Воениздат, 1972. $477 \mathrm{c}$.

14. Жуков Г. П., Викулов С.Ф. Военно-экономический анализ и исследование операций. Москва: Воениздат, 1987. 440 с.

15. Леонтьев В.В. Межотраслевая экономика Москва: ОАО «Издательство «Экономика», 1997. $479 \mathrm{c}$.

16. Ткач І. М. Концептуальні засади воєнноекономічної безпеки держави : 
монографія. Київ : НУОУ ім. І.

Черняховського, 2018. 312 с.

17. Tkach, M., Loyshyn, A., Kulinich, I., \& Polishchuk, A. (2020). Ways to create, maintain and increase the military-economic potential of the state. Journal of Scientific Papers "Social Development and Security», 10(3), 114-122. DOI: $10.33445 /$ sds.2020.10.3.10

\title{
Основные методологические аспекты оценки взаимосвязи оборонного и экономического потенциала государства в рамках формирования требований к его эффективному развитию
}

\author{
Олег Семененко * А; Сергей Салкуцан ${ }^{\text {; }}$ Ольга Романченко ${ }^{\text {; }}$ Евгений Марко ${ }^{\text {; }}$ \\ Людмила Добровольськая '; Артём Ремез ${ }^{\text {В }}$ \\ *Corresponding author: д. воен. н., с.н.с., начальник отдела, e-mail: aosemenenko@ukr.net, ORCID: 0000-0001-6477-3414 \\ А Центральный научно-исследовательский институт Вооружённых Сил Украины, пр-кт Воздухофлотский, 28, г. Киев, 03049, Украина

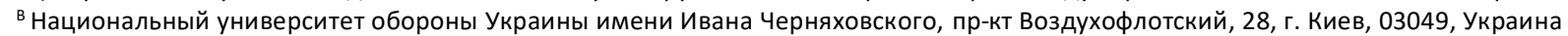 \\ ${ }^{c}$ Национальный авиационный университет, пр-кт Любомир Гузар, 1, г. Киев, 03058, Украина
}

\begin{abstract}
Аннотация
Национальные интересы Украины сегодня требуют немедленной разработки и внедрения комплекса мероприятий по обеспечению эффективного использования имеющихся ресурсов в целях экономического прогресса, увеличения и укрепления оборонного потенциала (ОП) и военно-экономического потенциала (ВЭП) государства. Исследование проблем оценки и сбалансированного развития ВЭП государства является одной из главных составляющих проблематики дальнейшего развития Украины в целом. Авторы в статье предприняли попытку раскрыть сущность понятий ОП и ВЭП государства с позиций военной науки. Приведенные в статье основные теоретические аспекты формирования ОП и ВЭП государства в современных условиях развития Вооруженных Сил (ВС) Украины и Украины позволят сформировать основные принципы в понимании этих понятий и их составляющих, определить их взаимосвязь в современной военной науке, а также выбрать основные направления проведения исследований по такой тематике. Анализ ВЭП и особенно его активной части (военной экономики) показывает, что состояние экономического обеспечения ОП Украины имеет сейчас значительные расхождения между его потребностями и вниманием, которое уделялось со стороны руководства государства его ресурсному обеспечению. Одной из основных проблем такого положения вещей является довольно значительные неопределенности в методологических аспектах его трактовки и оценки. Сегодня до основных задач совершенствования институционально-управленческого механизма государственного руководства по развитию ОП страны принадлежит необходимость модернизации процедур управления военно-экономической деятельностью, в частности систем военного финансирования, ценообразования на военную продукцию. Но это возможно реализовать в современных условиях развития ВС Украины и Украины в целом только в случае усовершенствования существующих процедур оценки достаточности ВЭП и ОП государства по основным составляющим их функционирования.
\end{abstract}

Ключевые слова: эффективность использования ресурсов, оборонный потенциал, военноэкономический потенциал, экономическое обеспечение, системы военного финансирования, уровень обороноспособности государства, военная экономика. 


\title{
Main methodological aspects of assessing the relationship between the defense and economic potential of the state in the framework of forming requirements for its requirements
}

\author{
Oleg Semenenko *A; Serhii Salkutsan ${ }^{B}$; Olha Romanchenko ${ }^{\text {B; }}$ Yevhen Marko ${ }^{\text {B; }}$; \\ Liudmyla Dobrovolska ${ }^{\text {; }}$; Artem Remez ${ }^{\text {B }}$
}

*Corresponding author: Dr of military sciences, Senior Research Fellow, Head of Department, e-mail: aosemenenko@ukr.net, ORCID: 0000-0001-6477-3414 ${ }^{A}$ Central Research Institute of the Armed Forces of Ukraine, 28, Povitroflotskyi Ave., Kyiv, 03049, Ukraine ${ }^{B}$ The National Defence University of Ukraine named after Ivan Cherniakhovskyi, 28, Povitroflotskyi Ave., Kyiv, 03049, Ukraine ' The National Aviation University, 1, Lubomyr Husar, Ave., Kyiv, 03058, Ukraine

\begin{abstract}
Today, the national interests of Ukraine need the immediate development and implementation of a set of measures to ensure the efficient use of available resources for economic progress, increase and strengthen the defense potential (DP) and military-economic potential (MEP) of the state. Research of problems of estimation and balanced development of MEP of the state is one of the main components of problems of further development of Ukraine as a whole. The authors of the article made an attempt to reveal the essence of the concepts of DP and MEP of the state from the standpoint of military science. The main theoretical aspects of the formation of DP and MEP of the state in the modern conditions of development of the Armed Forces (AF) of Ukraine and Ukraine as a whole will form the basic principles of understanding these concepts and their components, determine their relationship in modern military science, and choose the main directions of research on this topic. The analysis of MEP and especially its active part (military economy) shows that the state of economic support of the Ukrainian Armed Forces currently has significant differences between its needs and the attention paid by the state leadership to its resource provision. One of the main problems of this state of affairs is quite significant uncertainties in the methodological aspects of its interpretation and evaluation. Today, the main tasks of improving the institutional and management mechanism of state leadership for the development of the country's security include the need to modernize the procedures for managing military and economic activities, including military financing systems, pricing of military products and more. But it is possible to implement in the current conditions of development of the Armed Forces of Ukraine and Ukraine as a whole only in the case of improving the existing procedures for assessing the adequacy of MEP and DP of the state for the main components of their operation.
\end{abstract}

Keywords: use of available resources, defense potential, military-economic potential, economic support, military financing systems, level of state defense capability, military economy.

\section{References}

1. Problems and directions of development of the Armed Forces of Ukraine in modern conditions. URL: http://www.niss.gov.ua/content /articles /files/ZSU-73823.pdf.

2. Semenenko O, Boyko R, Vodchyts O, Dobrovolsky Yu., Berdochnyk D, Yaroshenok A Basic methodological aspects of militaryeconomic support of the state's defense capabilities: theory and practice // Information processing systems: quarterly. scientific and technical magazine. Kharkiv: KhNUPS, 2017. №
3 (51). Pp. 165-175.

3. Rud I. Sustainable Development Strategy "Ukraine 2020": goals, directions, priorities (Center for Social Communications Research). URL: http://nbuviap.gov.ua/index.php?option =com.

4. Semenenko O. Methodological bases of military-economic support of development programs of the Armed Forces of Ukraine: dis. ... Dr. troops. Sciences: 20.01.05 / Semenenko Oleg Mikhailovich. Kyiv: Central Research 
Institute of the Armed Forces of Ukraine, 2018. $640 \mathrm{p}$.

5. Vikulov S. Methodology for assessing the defense and military-economic potential of the state / Central Economic and Mathematical Institute of the Republic of Armenia. URL: https://cyberleninka.ru/article/n/metodologi ya-otsenki-oboronnogo-i-voenno-ekonomi cheskogo-potentsialov-gosudarstva / viewer.

6. Khrustalev E. Russia's defense potential in the context of modern international competition and globalization. URL: https://cyberleninka. ru/article/n/oboronnyy-potentsial-rossii-vkontekste-sovremennoy-mezhdunarodnoykonkurtsii-i-globalizatsii.

7. Muntiyan V. Economics and defense spending: analysis of foreign research and the Ukrainian way of development. Kyiv: Nauk.-doslid. Finn. Inst. at the Ministry of Finance of Ukraine, 1998. $463 \mathrm{p}$.

8. Chernyak O., Kharlamova O. Convergence of defense costs and economic development of the country // Bulletin of KNUTS. 2013. № 23. S. 36-41.

9. Semenenko O.M., Boyko R.V., Vodchyts O.G., Maslovsky S.S., Kremeshny O.I., Kornienko A.P The main methodological aspects of militaryeconomic justification of promising areas of development of the Armed Forces of Ukraine // Coll. Science. пр. ХНУПС. Kharkiv. 2018. № 1 (55). Pp. 37-45.

10. Substantiation of recommendations for improving the mechanism of formation of programs and plans for reform and development of the Armed Forces of Ukraine during defense planning: report on research "Meridian-OP" (final) / Central Research
Institute of the Armed Forces of Ukraine; ker. Potapov G.; executor: Semenenko O. and others. Kyiv. 2015. 137 p. № DR 0101U001854.

11. Semenenko O., Korniychuk S., Bokiy V., Kablukov O. Modern features of militaryeconomic support and assessment of the required level of defense of Ukraine // SDirect 24 - Safety, Society, Science. 2020. № 2 (12). R. 51-76. URL: https://www.sdirect24.org/kopianato-deep-no-13

12. "Try ATO years. Conclusions and prospects as of April 14, 2017", available at: [Three years ATO. Conclusions and prospects as at 14.04.2017] URL: https: // espreso.tv/.../2017/.../try_roky_ato_yak_ pochynalosya.

13. Radvik B. Military planning and analysis of systems abbr. translation from English $V$. Bazarova, L. Kakunina, K. Trofimova, ed. A. Parkhomenko Moscow: Voenizdat, 1972. 477 p.

14. Zhukov G., Vikulov S. Military-economic analysis and operations research. Moscow: Voenizdat, 1987. $440 \mathrm{p}$.

15. Leontiev V. Intersectoral economy / V Leontiev. Moscow: OJSC Ekonomika Publishing House, 1997. $479 \mathrm{p}$.

16. Tkach I.M. Conceptual principles of military and economic security of the state: monograph. Kyiv, 2018. $312 \mathrm{p}$.

17. Tkach, M., Loyshyn, A., Kulinich, I., \& Polishchuk, A. (2020). Ways to create, maintain and increase the military-economic potential of the state. Journal of Scientific Papers "Social Development and Security», 10(3), 114-122. DOI: $10.33445 /$ sds.2020.10.3.10 